\title{
Peningkatan Hasil Belajar Siswa Pada Mata Pelajaran Kimia Melalui Model Kooperatif Debat Kimia Berbasis ICT di Kelas XII la 2 SMA Negeri 2 Maumere
}

\author{
Hendrikus Hadir \\ SMA Negeri 2 Maumere, Sikka, NTT \\ Email : $\underline{\text { hadirhendrik66@gmail.com }}$
}

\begin{abstract}
Abstrak
Penelitian ini dilatarbelakangi oleh rendahnya ketuntasan hasil belajar siswa pada materi reaksi oksidasi dan reduksi. Tujuan penelitian ini adalah untuk mengetahui peningkatan hasil belajar siswa setelah diberikan model pembelajaran kooperatif debat kimia berbasis TIK. Bentuk penelitian yang digunakan adalah Penelitian Tindakan Kelas dengan subjek penelitian adalah siswa kelas XII IA SMA Negeri 2 Maumere. Teknik pengumpulan data yang digunakan adalah pengukuran dengan instrumen penelitian menggunakan tes hasil belajar dan observasi langsung menggunakan lembar pelaksanaan pembelajaran. Hasil penelitian menunjukkan bahwa hasil belajar siswa pada siklus I meningkat 3,78 menjadi 7,14 pada siklus II. Model kooperatif debat berbasis ICT dapat meningkatkan hasil belajar siswa.
\end{abstract}

Kata Kunci: Model Kooperatif, Debat Kimia, TIK

\section{PENDAHULUAN}

Pembelajaran merupakan bagian yang memiliki peranan sangat penting untuk mewujudkan kualitas pendidikan. Pembelajaran yang dilaksanakan secara baik dan tepat akan memberikan konstribusi sangat dominan bagi siswa, sebaliknya pembelajaran yang dilaksanakan dengan cara tidak baik akan menyebabkan potensi siswa sulit dikembangkan atau diberdayakan.Pada pelajaran kimia yang merupakan salah satu bagian dari sains, merupakan mata pelajaran yang mempelajari secara khusus materi, sifat, perubahan dan energi yang menyertai perubahannya. Pelajaran kimia diharapkan dapat membekali siswa dengan berbagai kemampuan tentang "cara mengetahui" dan "cara mengerjakan" yang dapat membantu siswa untuk memahami alam sekitar secara mendalam. Model pembelajaran yang dikembangkan perlu menekankan pada kegiatan belajar siswa aktif (active learning ) dan melakoninya langsung (learning by doing). Memperhatikan karakteristik pembelajaran sains tersebut, perlu dikembangkan beberapa pendekatan belajar dalam pembelajaran kimia yang aktif dengan menggunakan model pembelajaran kooperatif.

Model pembelajaran koperatif dapat mengaktifkan siswa dengan pembagian tugas secara individual sehingga siswa memiliki rasa tanggung jawab dan lebih aktif bertanya kepada teman sekelompok (Slavin, 2007). Model ini memberikan kesempatan kepada siswa untuk saling berbagi pemahaman baru dengan teman sekelasnya. Setiap anggota masing-masig mendapat spesialisasi tugas dan mengkaitkan antar konsep yang saling berhubungan (Nafia, 2013). 
Model pembelajaran kooperatif lebih memberikan peluang kesempatan kepada siswa untuk mempelajari apa yang mereka perlukan dan inginkan sehingga akan tercipta siswa yang aktif dan mandiri. Pusat Kurikulum (2002) menyatakan bahwa strategi pembelajaran aktif memberi ruang kepada pelajar untuk berinteraksi secara aktif dengan alat bantu belajar dan berfikir secara aktif. Priyadi (2010) berpendapat, pelajaran menggunakan metode ceramah akan berjalan membosankan dan siswa-siswa menjadi pasif karena tidak berkesempatan untuk menemukan sendiri konsep yang diajarkan.

Pada proses pembelajaran model kooperatif diskusi kelompok atau presentasi biasa di depan kelas, banyak siswa yang tidak aktif dalam kelompoknya, banyak kelompok yang hanya mengandalkan kawan kelompoknya, siswa ragu dan malu untuk mengemukakan pendapat, kelompok lain yang maju banyak yang pasif bahkan ada yang tidak mendengarkan, siswa bosan dan tidak bergairah, tidak semua siswa dalam kelompoknya aktif menjawab pertanyaan dari kelompok lain, kelompok yang menyajikan presentasinya kurang menarik dan membosankan sehingga banyak yang kurang mendengarkan atau mau terlibat dalam diskusi tersebut.

Pada akhirnya proses dengan menggunakan model diskusi kelompok biasa ini setelah dilaksanakan penilaian maka hasil belajarnya tidak mencapai target yang diinginkan. Berdasarkan data hasil penilaian yag diperoleh dari proses pembelajaran kooperatif debat biasa tanpa variasi yang telah dilaksanakan tidak memberikan hasil belajar yang diharapkan. Data hasil penilaian pembelajaran menggunakan model pembelajaran kooperatif debat biasa tanpa variasi di kelas XII IA 2 diperoleh ketidaktuntasan sebesar 70,37\% atau 19 siswa dari 27 siswa mendapat nilai dibawah KKM.

\section{METODE}

Penelitian ini merupakan penelitian tindakan kelas (PTK) yang terdiri dari perencanaan, pelaksanaan, pengamatan dan refleksi. Langkah-langkah yang dilakukan pada tahap perencanaan, antara lain: 1) Merancang Rencana Pelaksanaan Pembelajaran (RPP), dan (2) Menyusun instrumen penelitian yaitu kisi-kisi, soal diskusi, soal posttest, kunci jawaban dan pedoman pengskoran, dan lembar keterlaksanaan proses. Tahap pelaksanaan dilakukan dengan melaksanakan kegiatan pembelajaran menggunakan model kooperatif debat kimia berbasis ICT.

Tahap observasi dilakukan oleh observer yaitu guru Kimia di SMA Negeri 2 Maumere. Aspek yang diamati adalah kesesuaian antara keterlaksanaan proses pembelajaran dengan RPP. Tahap terakhir adalah refleksi, dimana peneliti dan observer berdiskusi membahas kekurangan-kekurangan yang dilakukan guru selama pembelajaran siklus berjalan dan memberikan saran untuk siklus berikutnya. Analisis data dilakukan menggunakan teknik deskriptif kuantitatif. 


\section{HASIL DAN PEMBAHASAN}

Pada penelitian ini, peneliti (sebagai guru) berkolaborasi dengan dosen program studi Pendidikan kimia membuat RPP dengan menyusun skenario tindakan model pembelajaran kooperatif debat kimia berbasis ICT. Penelitian ini terdiri dari dua siklus, tiap siklus dari tahap perencanaan, tindakan, observasi dan refleksi.

\section{Tahap Prasiklus}

Berdasarkan hasil observasi sebelum dilaksanakan siklus I, proses pembelajaran kooperatif debat biasa tanpa variasi yang telah dilaksanakan tidak memberikan hasil belajar yang maksimal. Data hasil penilaian pembelajaran menggunakan model pembelajaran kooperatif debat biasa tanpa variasi di kelas XII IA 2 diperoleh ketidaktuntasan siswa sebesar 70,37 \% atau 19 siswa dari 27 siswa mendapat nilai dibawah KKM. Model pembelajaran kooperatif bebat biasa tanpa variasi dan inovatif membuat siswa cenderung membosankan karena tidak semuanya siswa terlibat dan aktif.

\section{Pelaksanaan Pembelajaran}

Siklus I

Pembelajaran siklus I pada materi elektrolisis dilaksanakan hari Senin tanggal 3 September 2019. Tahap-tahap kegiatan dalam siklus I adalah sebagai berikut:

Tahap Perencanaan

Pada tahap perencanaan dirancang perangkat pembelajaran yaitu RPP menggunakan model pembelajaran kooperatif debat kimia berbasis ICT dan instrumen penilaian.

\section{Tahap Pelaksanaan Tindakan}

Tahap pelaksanaan pembelajaran dilakukan guru dengan langkah-langkah sebagai berikut:

a. Guru menyampaikan motivasi tentang materi redoks (materi pelajaran terdahulu) kemudian guru memotivasi para siswa pentingnya materi yang akan dipelajari dalam debat kimia serta memberi contoh yang berhubungan dengan materi ajar.

b. Guru melakukan aperspsi dengan mengajukan pertanyaan:

1) Dapatkah anda membedakan antara reaksi reduksi dengan reaksi oksidasi?

2) Dapatkah anda menyetarakan reaksi redoks dengan cara setengah reaksi?

3) Dapatkah anda membedakan sel volta dengan sel elektrolisis?

4) Dapatkah anda menuliskan reaksi suatu elektrolisis larutan elektrolit?

5) Dapatkah anda menjelaskan aplikasi proses elektrolisis dalam kehidupan sehari-hari?

6) Dapatkah anda menjelaskan fenomena korosi dalam kehidupan? 
c. Guru menuliskanTujuan pembelajarantentang "sel elektrokimia" kemudian menjelaskan bahan belajar tentang Macam- macam sel volta/galvani dan sel elektrolisis aplikasinya dalam kehidupan sehari-hari.

d. Guru membuat sebuah pernyataan yang kontroversi terhadap materi yang telah disampaikan yaitu: Beberapa siswa diminta pendapatnya hingga teridentifikasi ada pendapat yaitu pendapat yang setuju dan tidak setuju dengan ke empat kontroversial tersebut.

e. Guru membagi 2 kelompok peserta debat yang satu "pro" dan yang lainnya "kontra".

f. Guru memberikan tugas dan memerintahkan siswa untuk mencari bahan materi debat tersebut dan membuat laporan dalam media ICT, bisa power point,video dan animasi gambar. Setelah selesai membaca materi, guru menunjuk dengan cara mencabut undian tim mana yang maju untuk melaksanakan debat aktif dalam pembelajaran.

g. Guru membentuk sub kelompok dari tim siswa yang belum mendapat giliran sebagai tim pembela,penyanggah dan penengah dari setiap masing-masing tim Pro dan Kontra.

h. Guru memandu untuk memulai "perdebatan" dan dalam perdebatan ini guru bertindak sebagai pemandu.

i. Langkah pertama, memerintahkan "juru bicara" dari kelompok "penyaji" dari tim pro untuk menyampaikan argumen-argumennya.

j. Langkahkedua,meminta kelompok kontra untuk memberikan atau menyampaikan "konter argumentasinya" dan buatlah situasi debat antara tim pro dengan kontra dan sesekali meminta argumentasi dari kelompok "penengah". Langkah ketiga, mintalah kelompok "pembela" untuk menyampaikan argumentasi pembelaanya dan buatlah situasi debat antara kelompok kontra dengan kelompok "pembela" dan sesekali meminta argumentasi dari kelompok" penengah".

k. Guru memotivasi peserta yang lain untuk mencatat jawaban berbagai argumen atau bantahan yang disarankan kepada juru bicaranya.

I. Ketika dianggap perdebatannya sudah cukup, guru mengakhiri perdebatan tersebut dan meminta tim yang telah maju dalam debat aktif untuk bergabung kembali dengan menggabungkan kembali seluruh kelompok tersebut dalam lingkaran penuh.

$\mathrm{m}$. Sementara siswa menyampaikan gagasannyagurumenulis inti/ide-ide dari setiap pembicaraan di papan tulis, sampai sejumlah ide yang diharapkan guru terpenuhi.

n. Guru menambahkan konsep/ide yang belum terungkap.

o. Ketika dianggap perdebatannya sudah cukup, guru mengakhiri perdebatan tersebut dan meminta tim yang telah maju dalam debat aktif untuk bergabung kembali dengan menggabungkan kembali seluruh kelompok tersebut dalam lingkaran penuh.

p. Berdasarkan data-data di papan tulis terbut, guru mengajak siswa membuat kesimpulan/rangkuman yang mengacu pada tujuan yang ingin dicapai. Kemudian disimpulkan dan guru memberi komentar tentang permasalahan yang diajukan dalam perdebatan tersebut serta membuat diskusi seluruh kelas tentang apa yang telah dipelajari oleh siswa tentang persoalan dari dari pengalaman debat itu dan kemudian merumuskan 
argumen-argumen terbaik yang dibuat kedua kelompok (pro dan kontra) debat tersebut.

q. Sebelum ditutup dan mencabut undian yang berikutnya,guru mendorong semua siswa untuk menyambut dengan applaus atas debat yang telah dilakukan detelah itu mempersilahkan dengan memotivasi tim.

Tahap observasi

Model yang digunakan pada siklus I kooperatif tife debat kimia berbasis ICT. Topik yang diperbedatkan adalah pencegahan korosi secara mekanik lebih efektif dibandingkan dengan cara lain (reduksi katodik), Namun cara ini teramati kurang efektif karena siswa yang akan berpendapat telah ditentukan sebelumnya, sehingga hanya siswa yang akan berpendapat saja yang memperhatikan pembelajaran siswa yang menggunakan handphone untuk mencari informasi yang akan digunakan dalam mengemukakan pendapat tanpa memperhatikan jalannya diskusi. Guru telah berupaya membuat siswa di dalam tim pembela (pro), penyanggah (kontra), dan penengah aktif dengan meminta mereka membuat laporan hasil diskusi yang dikumpulkan pada akhir pembelajaran, namun hasil pengamatan terdapat siswa yang melihat laporannya temannya untuk membuat laporan hasil diskusi.

\section{Tahap Refleksi}

Refleksi dilakukan untuk memperbaiki proses pembelajaran pada siklus berikutnya. Berdasarkan evaluasi pada tahap refleksi siklus I, disepakati pada siklus II guru akan menunjuk siswa di dalam tim pembela (pro), penyanggah (kontra), dan penengah secara acak untuk mengemukakan pendapat, dimana cara ini terlebih dahulu disosialisasikan guru pada awal pertemuan.

Siklus II

Pembelajaran siklus II pada materi elektrokimia pada hari Selasa tanggal 4 September 2019. Tahap-tahap yang dilakukan pada siklus II sama dengan siklus I yaitu perencanaan, tindakan, observasi dan refleksi.

Tahap Perencanaan

Pada tahap perencanaan dirancang perangkat pembelajaran yaitu rencana pelaksanaan pembelajaran menggunakan model pembelajaran kooperatif debat kimia berbasis ICT, dan instrumen penilaian.

Tahap Pelaksanaan Tindakan

Tahap pelaksanaan dilaksanakan seperti pada siklus I, akan tetapi untuk teknis penunjukkan siswa dalam presentasi dan menjawab pertanyaan dilakukan guru secara acak.

\section{Tahap Observasi}

Topik debat yang digunakan adalah apakah sel aki kering lebih efektif dibandingkan dengan sel aki basah? Pada siklus II guru melaksanakan hasil refleksi pada siklus I dengan metode yang digunakan adalah debat dan tanya jawab, sehingga siswa teramati lebih memperhatikan jalannya debat. 
Berdasarkan hasil pengamatan observer sebagian besar siswa telah memperhatikan jalannya debat dan membuat laporan hasil debat, namun dalam pelaksanaan debat antara tim penyaji terjadi saling memotong pembicaraan, sehingga membuat penjelasan yang diberikan dari masing-masing tim menjadi tidak utuh. Guru telah berupaya untuk mencegah hal tersebut terjadi dengan membuat atuan main di dalam debat dan disampaikan sebelum siklus I dilaksanakan, akan tetapi pada pembelajaran siklus II aturan tersebut tidak dilaksankan dengan baik, akibatnya debat antara tim penyaji menjadi kurang efektif.

Tahap Refleksi

Berdasarkan hasil diskusi pada tahap refleksi siklus II, disarankan guru untuk menunjuk moderator yang berasal dari siswa untuk mengatur jalannya diskusi, sehingga tidak terjadi saling memotong pembicaraan pada saat berargumen.

Peningkatan Hasil Belajar Siswa Peningkatan hasil belajar siswa dalam proses pembelajaran dapat dilhat dari nilai posttest disetiap siklusnya. Nilai posttest tersebut dapa dilihat ada beberapa siswa yang berhasil mencapai nilai KKM $(K K M \geq 80)$ dan dikatakan tuntas, dan beberapa siswa yang tidak berhasil mencapai nilai KKM tersebut. Gambar berikut ini menyajikan persentase ketuntasan hasil belajar siswa yang diperoleh dari hasil posttest siswa dalam dua siklus.

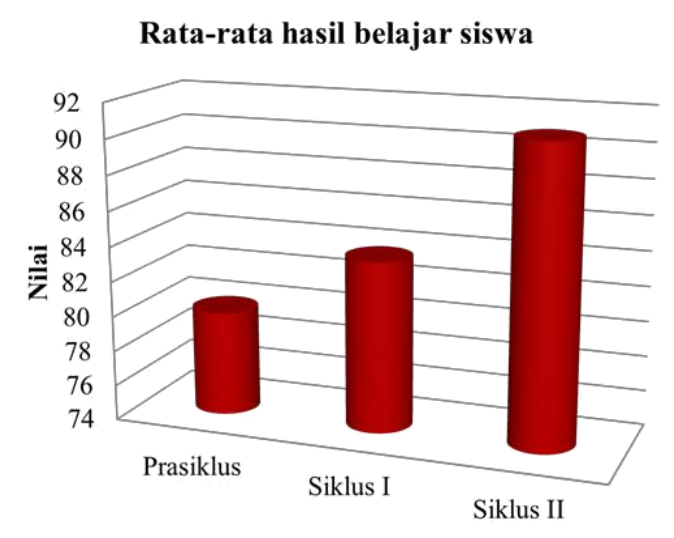

Gambar 1. Persentase Ketuntasan Hasil Belajar Siswa pada Siklus I dan Siklus II

Berdasarkan gambar di atas terlihat terdapat peningkatan ketuntasan hasil belajar siswa dari prasiklus ke siklus I sebesar 3,78 dan dari siklus 1 ke siklus II sebesar 7,14. 12,75\%. Indikator ketuntasan hasil belajar siswa pada siklus I sebesar 48,65\% dan meningkat pada siklus I sebesar 91,89. Pada siklus II seluruh siswa telah mencapai ketuntasan hasil belajar (100\%)

\section{KESIMPULAN}

Simpulan pada penelitian ini adalah model pembelajaran kooperatif debat kimia berbasis ICT dapat meningkatkan hasil belajar siswa sebesar 3,78 pada siklus I, menjadi 7,14 pada siklus II. Saran pada penelitian ini adalah sebaiknya alokasi waktu pada debat kimia harus diperhitungkan secara tepat sehingga setiap tahap dapat terlaksana dengan baik. 


\section{DAFTAR PUSTAKA}

Arikunto, S dkk. 2006. Prosedur Penelitian suatu Pendekatan Praktik (Edisi Revisi V). Jakarta: Asdi Mahasatya.

Mansur, S. 2018. Aplikasi Asesmen Dalam Pembelajaran IPA di Kelas IV Sekolah Dasar Negeri Gelogor. Universitas Muhammadiyah Makasar. Jurnal Riset Pendidikan Dasar. 1 (1): 49-55. DOI: http://dx.doi.org/10.26618/jrpd.v1i1.1239

Mansur, S. 2018. Penerapan Model Pembelajaran Kooperatif Tipe STAD untuk Meningkatkan Motivasi dan Hasil Belajar pada Konsep Ekosistem di SMA Negeri 2 Maumere. STAI Darul Kamal NW Kembang kerang. Jurnal Al$\begin{array}{lllll}\text { Muta'aliyah. } & 1 & (1): & 117-127 .\end{array}$ http://ejournal.kopertais4.or.id/sasambo/index.php/mutaaliyah

Mansur, S (2018). Pengaruh Pendekatan Jelajah Alam Sekitar (JAS) Terhadap Hasil Belajar Siswa pada Materi Klasifikasi Mahluk Hidup di SMPK Binawirawan Maumere. BIOEDUSCIENCE: Jurnal Pendidikan Biologi Dan Sains, 2(1), 74-80. https://doi.org/10.29405/j.bes/2174-801314

Mansur S, Bare. Y. (2019) Meningkatkan Hasil Belajar Siswa pada Konsep Perubahan dan Pelestarian Lingkungan Hidup dengan Model Discovery Learning di SMAS Katolik ST Gabriel Maumere, BIOEDUSCIENCE: Jurnal Pendidikan Biologi dan Sains: Vol. 3 No. 2

Nafia, I. 2013. Meningkatan Aktivitas dan hasil belajar mengelola konflik dengan CO-OP siswa $X$ BB2(online). (http://www.slametpriyadi.com/2011 109/19/kelebihan-keku-rangan-metode-ceramah-dalam pembelajaran/, Diakses 21 april 2019).

Rofiq, M. N. 2010. Pembelajaran Koperatif dalam Pengajaran Islam. Jurnal FALASIFA vol. 1 No. 1 Maret 2010.

Rusman. 2012. Model-Model Pembelajaran. Edisi Kedua. Rajagrafindo Persada: Jakarta.

Slavin, R E. 2007. Cooperative Learning Teotri, Riset dan Praktek. Bandung: Nusa Media. 